\title{
Analisis Laporan Kejadian Jatuh pada Pasien Lansia Saat Rawat Inap di Rumah Sakit Immanuel Bandung Periode 2014-2016
}

Analysis on falls incident reports of elderly patients hospitalized at Immanuel Hospital Bandung in the period of 2014-2016

\section{Vera}

Fakultas Kedokteran, Universitas Kristen Maranatha

Jl Surya Sumantri no 65 Bandung

Email: omaopasehat@gmail.com

Received: November 16, 2020

Accepted: August 1, 2021

\begin{abstract}
Abstrak
Jatuh merupakan salah satu masalah yang dominan terjadi pada lansia. Jatuh didefinisikan sebagai suatu kejadian yang mendadak, tidak diharapkan, dan tidak disengaja yang menyebabkan pasien berada di tanah atau level yang lebih rendah. Penelitian ini merupakan penelitian deskriptif, menggunakan data laporan kasus jatuh yang masuk ke komite patient safety, dengan tujuan untuk mengetahui karakteristik klinis dari pasien lansia yang jatuh saat dirawat inap di Rumah Sakit Immanuel Bandung. Selama periode 2014-2016, didapatkan 12 laporan kejadian pasien lansia jatuh saat dirawat inap di Rumah Sakit Immanuel, komorbiditas yang paling banyak adalah diabetes melitus. Simpulan yang didapat, kejadian jatuh pada pasien lansia yang dirawat inap di RS Immanuel lebih banyak terjadi pada wanita dengan usia > 60 tahun, terjadi malam hari, di sekitar tempat tidur, dan saat tidak didampingi. Konsumsi lebih dari satu obat oleh pasien lansia sebaiknya dihindari karena berpotensi meningkatkan risiko jatuh dan menyebabkan hasil perawatan kurang baik.
\end{abstract}

Kata kunci: jatuh, lansia, rawat inap

\begin{abstract}
Falls are one of the dominant problems in the elderly. A fall is defined as a sudden, unexpected, and accidental event causing the patient to be on the ground or lower level. This is a descriptive study using a fall report received by the patient safety committee, aiming to describe the clinical characteristics of elderly patients who fell while being hospitalized at Immanuel Hospital Bandung. Between 2014-2016, there were 12 fall incident reports of hospitalized elderly patients at Immanuel Hospital, with diabetes mellitus as the most commonly found comorbidities. In a conclusion, the incidence of falls in elderly patients who are hospitalized at Immanuel Hospital is more common in women, aged $>60$ years, occurs at night, around the bed, and when unaccompanied. Consumption of polypharmacy by elderly patients should be avoided because it has the potential to increase the risk of falling and causes poor treatment outcome.
\end{abstract}

Keywords: fall, elderly, hospitalized 


\section{Research Article}

\section{Pendahuluan}

Lanjut usia (lansia) adalah seseorang yang mencapai usia 60 tahun ke atas, berdasarkan Undang-Undang Nomor13 Tahun 1998 tentang Kesejahteraan Lanjut Usia. Secara global populasi lansia diprediksi terus mengalami peningkatan. Populasi lansia di Indonesia diprediksi meningkat lebih tnggi dari pada populasi lansia di dunia setelah tahun 2100. Pada tahun 2013, proporsi penduduk lansia di Indonesia mencapai 8,9\% dan dunia 13,4\%. ${ }^{1}$ Jatuh merupakan salah satu masalah yang dominan terjadi pada lansia. Jatuh didefinisikan sebagai suatu kejadian yang mendadak, tidak diharapkan dan tidak disengaja yang menyebabkan pasien berada di tanah atau level yang lebih rendah. Kejadian jatuh pada pasien lanjut usia yang dirawat inap di rumah sakit sering terjadi dengan 2,3 hingga 7 kejadian jatuh per 1000 pasien setiap harinya. Sekitar 30\% dari pasien yang dirawat inap mengalami luka dengan $4 \%$ hingga $6 \%$ nya mengalami jejas berat. Jejas berat yang dimaksud dapat berupa fraktur, hematoma subdural, perdarahan, bahkan kematian. Cedera yang diakibatkan oleh jatuh meningkatkan biaya pengobatan di rumah sakit. Rerata waktu rawat tambahan yang dibutuhkan setelah pasien jatuh adalah 12,3 hari. ${ }^{2,3}$

Jatuh pada lansia dipengaruhi oleh beberapa faktor, yaitu faktor mobilitas (mobility), faktor perilaku pengambilan risiko (risk taking behavior), serta faktor kondisi lingkungan (physical environtment). Pengelompokan faktor yang mempengaruhi jatuh pada lansia yang lain adalah faktor internal, dari diri lansia, dan eksternal, dari luar diri lansia. Beberapa penelitian sebelumnya telah mengidentifikasi faktor risiko terjadinya jatuh di rumah sakit seperti terganggunya keseimbangan, mobilitas, riwayat jatuh sebelumnya, bertambahnya usia, gangguan kognitif, depresi, pusing atau vertigo, hipotensi ortostatik, gangguan visual dan penggunaan obatobatan seperti benzodiazepin, antipsikotik, serta sedatif.-4 Sebagian besar rumah sakit belum terbiasa melengkapi sistemnya untuk pencegahan jatuh pada lansia, terutama yang disertai dengan masalah kesehatan mental. ${ }^{5}$ Pencegahan jatuh pada pasien merupakan aspek yang penting bagi penanganan keamanan pasien terutama lansia yang kebanyakan datang dengan ganguan keseimbangan dan memiliki risiko tinggi fraktur. Komplikasi fatal pada lansia kebanyakan diakibatkan oleh jatuh. ${ }^{6}$

Tujuan dari penelitian ini adalah untuk mengetahui karakteristik klinik dari pasien lansia yang jatuh saat dirawat inap di Rumah Sakit Immanuel Bandung periode 2014 hingga 2016. 


\section{Research Article}

\section{Metode}

Penelitian ini merupakan penelitian deskriptif retrospektif dan telah mendapat persetujuan dari tim kaji etik Fakultas Kedokteran Universitas Kristen Maranatha. Daftar nama pasien berusia $\geq 60$ tahun yang diopname di RS Immanuel Bandung dan dilaporkan jatuh pada komite patient safety RS Immanuel selama tahun 2014-2016 dicatat. Rekam medis pasien tersebut ditinjau dan dipindahkan datanya ke lembar data. Variabel penelitian meliputi identitas pasien (jenis kelamin dan usia), daftar masalah, waktu, tempat, pendamping, kondisi, dan implikasi jatuh pada pasien, keterlibatan pengaruh obat, dan hasil perawatan pasien.

\section{Hasil}

Didapatkan 12 laporan kasus jatuh pada lansia yang dirawat inap di RS Immanuel selama periode 2014-2016 yang diterima oleh komite patient safety, dengan karakteristik klinis seperti terlihat pada tabel 1.

Berdasarkan tabel 1, tampak bahwa $67 \%$ pasien lansia yang dilaporkan jatuh saat rawat inap adalah berjenis kelamin perempuan. Komorbiditas yang mendominasi adalah diabetes melitus (58\%). Kondisi kesadaran pasien saat jatuh sebagian besar (58\%) adalah compos mentis. Pada 58\% laporan pasien lansia yang jatuh saat dirawat inap, pasien membaik dan pulang. 25\% pasien pulang atas permintaan sendiri, seluruhnya adalah pasien dengan dementia/delirium, karena keluarga sudah kewalahan mendampingi pasien gaduh gelisah selama dirawat inap di rumah sakit.

Gambar 1 menunjukkan penggunaan obat yang berpotensi meningkatkan risiko jatuh pada pasien lansia yang dirawat inap dan mengalami kejadian jatuh. Konsumsi obat yang berpotensi meningkatkan risiko jatuh yang paling banyak adalah jenis analgetik non NSAID.

Di antara 3 orang pasien lansia yang mengonsumsi lebih dari satu jenis obat berpotensi meningkatkan risiko jatuh, setelah dirawat ternyata tidak ada yang membaik, bahkan 1 orang meninggal seperti dapat dilihat pada gambar 2. Kelompok ini terbagi menjadi pasien yang mengonsumsi kombinasi obat analgetik dan antihipertensi (2 orang) serta pasien yang mengonsumsi kombinasi antipsikotik dan neuroleptik (1 orang). 


\section{Research Article}

Tabel 1. Karakteristik Klinis Pasien Lansia yang Mengalami Jatuh Saat Rawat Inap Periode 2014-2016

\begin{tabular}{lcc}
\hline Variabel & Jumlah & \% \\
\hline Jenis kelamin & & \\
Perempuan & 8 & 67 \\
Laki- laki & 4 & 33 \\
Umur (tahun) & & \\
$60-69$ & 3 & 25 \\
$70-79$ & 6 & 50 \\
$\geq 80$ & 3 & 25 \\
Komorbiditas & & \\
DM saja & 3 & 25 \\
Stroke saja & 1 & 8 \\
Delirium/Dementia & 1 & 8 \\
DM + Dementia & 1 & 8 \\
DM + Stroke & 1 & 8 \\
Tidak ada & 5 & 25 \\
Kondisi Pasien Saat Jatuh & & \\
Compos mentis & 7 & 58 \\
Delirium & 1 & 8 \\
Tidak ada data & 4 & 34 \\
Hasil Perawatan & & \\
Pulang atas permintaan sendiri & 3 & 25 \\
Meninggal & 2 & 17 \\
Membaik & 7 & 58 \\
\hline
\end{tabular}

\section{Jenis obat yang meningkatkan risiko jatuh}

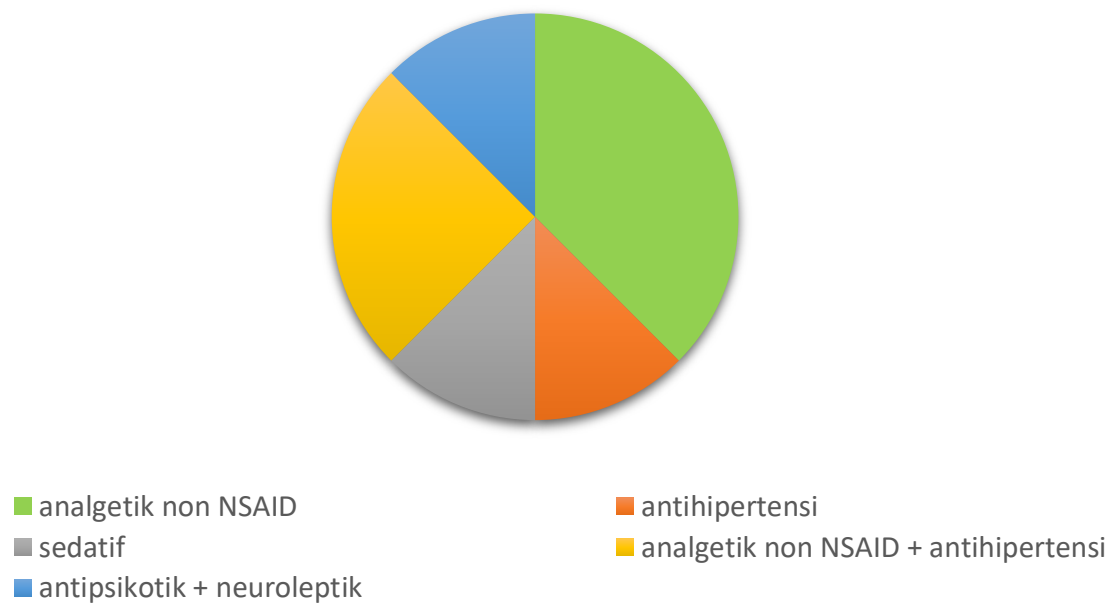

Gambar 1 Jenis Obat yang Meningkatkan Risiko Jatuh pada Pasien Lansia Rawat Inap 


\section{Research Article}

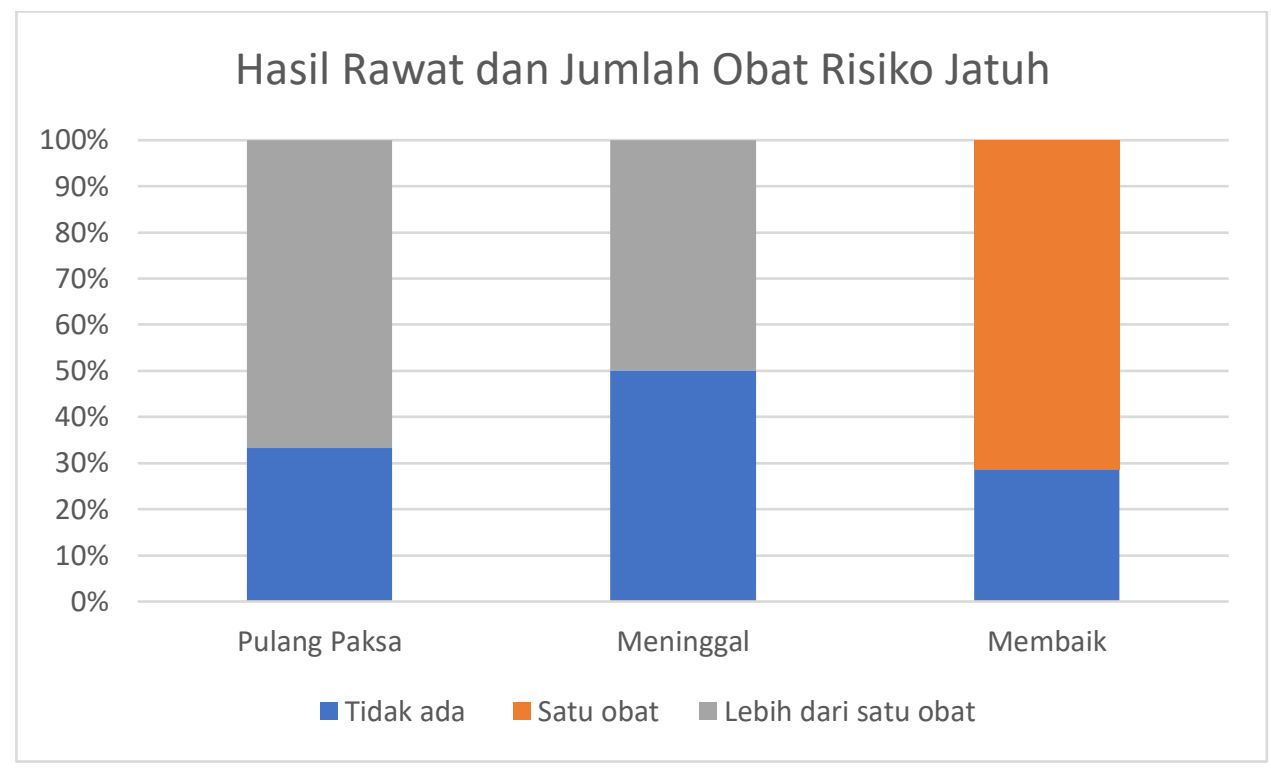

\section{Gambar 2 Hasil Perawatan dan Jumlah Obat yang Meningkatkan Risiko Jatuh pada Pasien Lansia Rawat Inap}

Gambar 3 menunjukkan bahwa tempat jatuh tersering pada pasien lansia yang diopname adalah di sekitar tempat tidur, sedangkan Gambar 4 menunjukkan waktu kejadian jatuh paling sering adalah malam hari antara pukul 18.00-24.00.

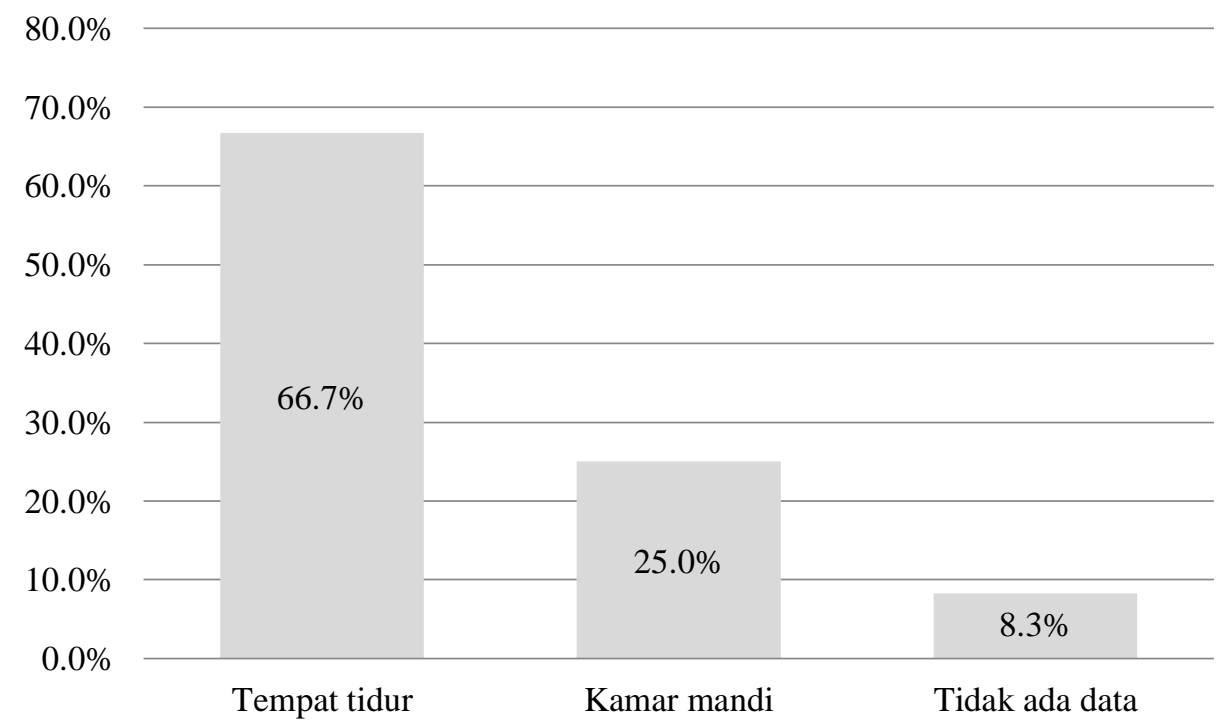

Gambar 3 Tempat Kejadian Lansia Jatuh 


\section{Research Article}

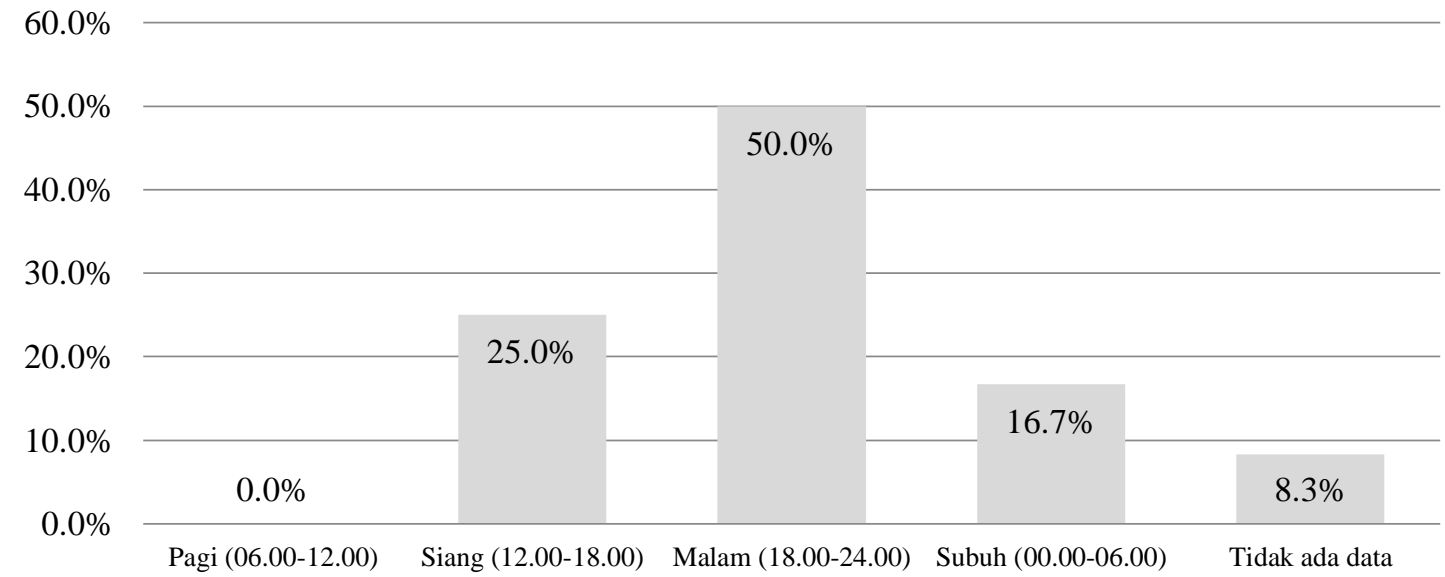

Gambar 4 Waktu Kejadian Jatuh pada Lansia

Berdasarkan gambar 5, terlihat bahwa sebagian besar kejadian jatuh pada pasien lansia yang dirawat inap terjadi saat pasien sendirian, tanpa pendamping. Hal yang perlu dicermati adalah pada seperempat (25\%) kasus jatuh pada pasien lansia yang dirawat inap ternyata tidak ditemukan data pada status rekam medisnya.

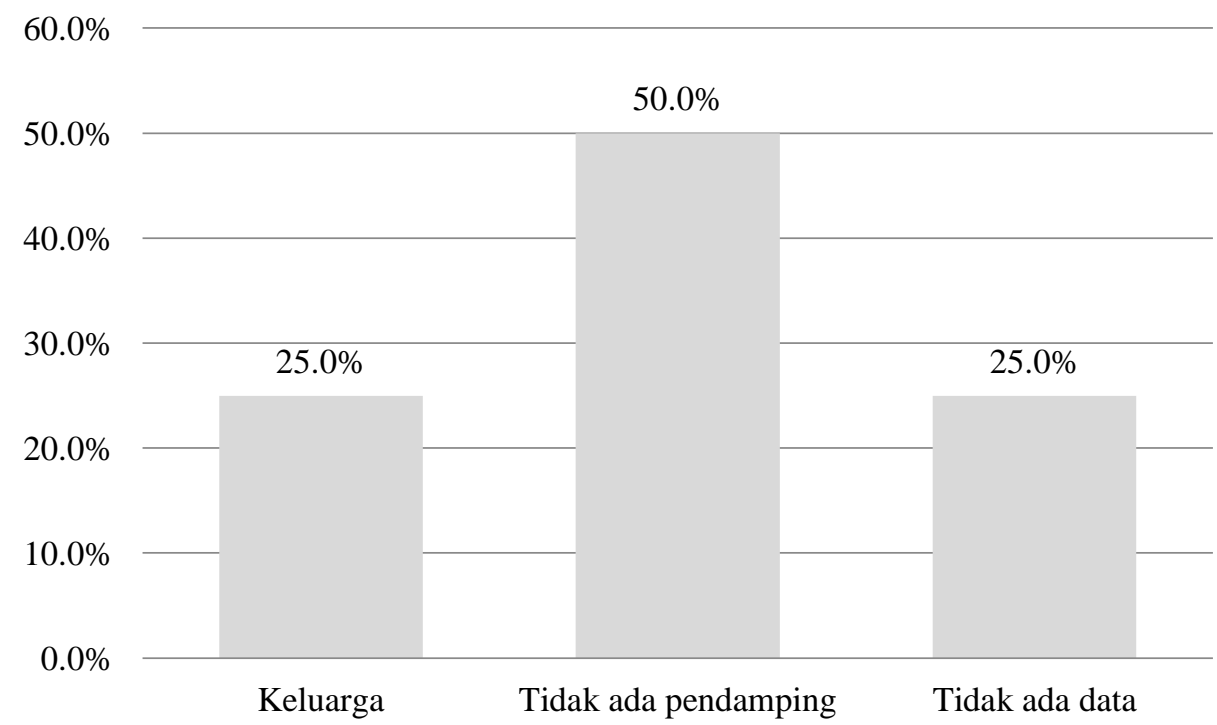

Gambar 5 Ada Tidaknya Pendamping Saat Kejadian Jatuh pada Lansia 


\section{Research Article}

Pada gambar 6 terlihat bahwa sebagian besar pasien yang jatuh tidak mengalami cedera, namun yang perlu dicermati adalah pada sepertiga kasus jatuh pada pasien lansia yang dirawat inap juga tidak ditemukan data cedera pada status rekam medisnya. Nampaknya ketertiban pencatatan data masih kurang di kalangan tenaga kesehatan.

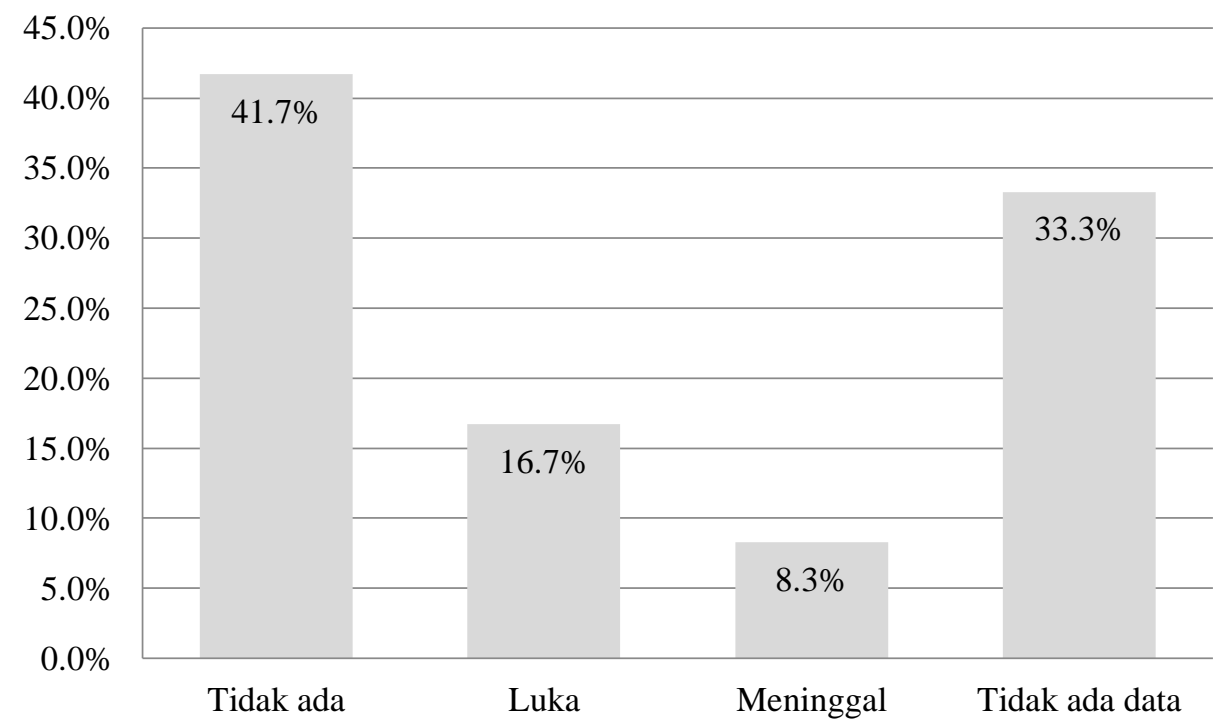

Gambar 6 Implikasi Akibat Jatuh pada Pasien Lansia Rawat Inap

\section{Diskusi}

Penyebab dari seluruh kejadian jatuh apada lansia berkaitan erat dengan kondisi fisik atau perilaku pasien, medikasi, personal, lingkungan, dan faktor fasilitas. ${ }^{7}$ Kejadian jatuh pada penelitian ini menujukkan lebih banyak dialami oleh wanita dibandingkan pria. Hal ini sesuai dengan studi yang dilakukan di Swedia yaitu wanita memiliki risiko jatuh yang lebih tinggi dibandingkan dengan pria. Faktor-faktor yang dapat mempengaruhi hal tersebut dibandingkan dan dianalisis. Peningkatan risiko jatuh tersebut berkaitan dengan variasi dari pola gerak saat melakukan aktivitas lebih dari satu yang berkontribusi terhadap tingginya risiko fraktur akibat jatuh pada wanita dibandingkan pria. ${ }^{8}$ Kelompok umur pasien lansia yang paling sering dilaporkan jatuh berada pada rentang 70-80 tahun, sementara pada penelitian yang sebelumnya dikatakan bahwa kejadian jatuh paling sering dialami oleh lansia berusia 85 tahun atau lebih, perbedaan ini mungkin dipengaruhi oleh jumlah pasien yang dianalisis tidak sebanyak penelitian sebelumnya. ${ }^{9}$ 


\section{Research Article}

Penggunaan obat pada populasi lansia telah meningkat pada dekade terakhir. Mayoritas orang berusia lebih dari 55 tahun (72\%) menggunakan sedikitnya satu obat. Reaksi obat yang tidak diinginkan/adverse drug reactions (ADRs) dapat menyebabkan morbiditas dan mortalitas yang signifikan. Dua per tiga dari perawatan yang diakibatkan oleh ADR terjadi pada mereka yang berusia $>60$ tahun dengan mortalitas $8-10 \%$. Lansia lebih rentan terhadap terjadinya ADR akibat lingkungan sosial, polifarmasi, komorbiditas, gangguan kognitif dan perubahan fisiologi yang mempengaruhi farmakokinetik dan farmakodinamik.

Tempat pasien terjatuh paling banyak terjadi pada daerah sekitar tempat tidur $(66,7 \%)$ diikuti dengan kamar mandi (29\%), seperti pada penelitian sebelumnya dengan 65-85\% pasien ditemukan jatuh di kamar tidur dan 11-29\% di kamar mandi. ${ }^{10}$

Gambar 2 dan 3 menunjukkan jatuh banyak terjadi saat malam hari yaitu dari pukul 18.00 hingga 24.00 (50\%) dan sebagian besar pasien tidak didampingi saat jatuh (67\%). Pasien tidak mendapatkan pendampingan saat jatuh. Jika kejadian jatuh terjadi pada periode malam hari dapat mengakibatkan kebingungan dan agitasi pada sebagian pasien. Pasien merasa tidak familiar terhadap lingkungan rumah sakit saat malam hari, bersamaan dengan rasa enggan untuk mengganggu pendamping ataupun perawat. ${ }^{10}$ Kebingungan merupakan penyebab kedua dari kejadian jatuh yang dilaporkan pada tahun 2009. Menurut sebuah studi systematic literature review, kejadian jatuh paling sering terjadi pada periode paling aktif pada pasien, yang bervariasi antar satu rumah sakit dengan yang lainnya. ${ }^{11}$ Kejadian jatuh tanpa dampingan di rumah sakit dilaporkan mencapai $79 \%$ dan sebagian besar dikarenakan pasien mencoba untuk beraktivitas sendiri. Pada penelitian ini, sebagian besar dari pasien (58\%) dalam kesadaran dan orientasi baik. Pasien sadar dan mungkin berusaha mengerjakan aktivitas sendiri. ${ }^{2}$

Kejadian jatuh pada pasien rawat inap sering terjadi dan memengaruhi sekitar 2\% hingga $17 \%$ pasien saat perawatan di rumah sakit. Jejas yang diakibatkan oleh jatuh terjadi pada 15\%$50 \%$ pasien, termasuk luka berat seperti fraktur atau laserasi (1-10\%), bahkan kematian pada $<1 \%$ kejadian jatuh. Jatuh juga dapat mengakibatkan hambatan aktivitas pergerakan pasien secara psikis karena merasa takut akan jatuh lagi, dan memperpanjang durasi perawatan di rumah sakit. ${ }^{12}$ Pada penelitian ini, ditemukan satu pasien dengan gagal jantung kongestif, bronkopneumonia dan penyakit jantung koroner dan ditemukan telah meninggal setelah jatuh. Satu pasien lainnya dengan stroke dan DM tipe 2 akhirnya meninggal di High Care Unit setelah jatuh di ruang rawat inap biasa. Dua pasien yang mengalami luka ringan berupa hematoma, salah satunya memiliki riwayat stroke, risiko jatuh tinggi dengan bantuan total untuk kegiatan motoriknya dan pasien satunya dengan kondisi bantuan sebagian terjatuh terpeleset di kamar mandi. Data dari tujuh 


\section{Research Article}

pasien lainnya tidak dilaporkan. Sekitar 58\% pasien pulang dengan kondisi membaik setelah jatuh saat dirawat inap.

Skrining awal risiko jatuh berupa penilaian status nutrisi, sensorik, kognitif dan motorik penting dilakukan pada pasien yang akan menjalani rawat inap di rumah sakit. Stabilitas postural merupakan kemampuan kompleks yang bergantung pada koordinasi sistem motorik dan sensoris untuk memahami stimulus lingkungan dan respons terhadap gangguan dalam mengontrol gerakan tubuh. Sistem motorik dan sensoris berhubungan dengan proses neurologi dan kognisi yang dibutuhkan untuk merencanakan gerakan, membagi atensi dan merespon terhadap lingkungan. Gangguan kognitif telah diidentifikasi sebagai salah satu faktor risiko jatuh. ${ }^{13}$ Pada penelitian ini, sebagian besar pasien (67\%) memiliki status kognitif dan sensorik yang baik, namun sebagian besar pasien $(75 \%)$ memiliki fungsi motorik yang terganggu sehingga harus dibantu oleh orang lain dalam rangka perawatan diri selama rawat inap di rumah sakit. Keluaran jatuh pada pasien akan lebih buruk apabila fungsi kognitif, sensorik dan motorik tersebut terganggu. ${ }^{14,15}$ Keparahan risiko jatuh akan meningkat apabila terdapat gangguan pada ketiga fungsi tersebut. Pada lansia lemah dan ringkih dan hal tersebut di atas penting untuk diidentifikasi karena merupakan isu yang signifikan dan dapat meningkatkan risiko jatuh dan berkaitan dengan penyakit bahkan kematian. ${ }^{16}$ Pada penelitian ini, terdapat 33,3\% pasien dengan status nutrisi terganggu dengan indeks massa tubuh $<20 \mathrm{~kg} / \mathrm{m} 2$ dan jumlah asupan makan yang kurang dalam seminggu terakhir. Hal ini dapat meningkatkan risiko jatuh pada pasien lansia, akibat kelemahan otot tungkai bawah yang dialaminya.

Keterbatasan penelitian ini adalah jumlah populasi pasien yang sedikit. Hal ini mungkin karena pelaporan kejadian jatuh pada pasien lansia hanya dilakukan apabila implikasi jatuh merupakan sesuatu yang serius, yang berpotensi menimbulkan tuntuan hukum dari keluarga pasien. Perlu dilakukan upaya-upaya untuk meningkatkan kesadaran staf RS agar dapat mencatat dan melaporkan kejadian jatuh pada pasien lansia secara detil, meskipun tidak berakibat cedera serius, sehingga dapat dirancang suatu program pencegahan jatuh yang efektif dan efisien.

\section{Simpulan}

Kejadian jatuh pada pasien lansia yang dirawat inap di RS Immanuel lebih banyak terjadi pada wanita dengan usia > 60 tahun, terjadi malam hari, di sekitar tempat tidur, dan saat tidak didampingi. Konsumsi lebih dari satu obat oleh pasien lansia sebaiknya dihindari karena berpotensi meningkatkan risiko jatuh dan menyebabkan hasil perawatan kurang baik. 


\section{Research Article}

\section{Daftar Pustaka}

1. Indonesia KKR. Infodatin - Situasi Lanjut Usia (LANSIA) di Indonesia. In: Indonesia KKR, editor. Jakarta: Kemenkes 2016.

2. Hitcho EB, Krauss MJ, Birge S, Dunagan WC, Fischer I, Johnson S, et al. Characteristics and Circumstances of Falls in a Hospital Setting: A Prospective Analysis. Journal of General Internal Medicine. 2004;19(7):732-9.

3. Gu Y-Y, Balcaen K, Ni Y, Ampe J, Goffin J. Review on Prevention of Falls in Hospital Settings. Chin Nurs Res 2016;3(1):7-10.

4. Foundation CfDCC. Check for Safety. A Home Fall Prevention Checklist for Older Adults. In: Foundation M, editor. USA: Departement of Health and Human Services Centers for Disease Control and Prevention; 2005.

5. Oliver D. Preventing falls and fall injuries in hospital: a major risk management challenge. SAGE Journals. 2007;13(5):173-8.

6. Zhang C, Wu X, Lin S, Jia Z, Cao J. Evaluation of Reliability and Validity of the Hendrich II Fall Risk Model in a Chinese Hospital Population. PLOS ONE. 2015;10(11):e0142395.

7. Tsai L-Y, Tsay S-L, Hsieh R-K, Yu S, Tsai J-M, Chien H-H, et al. Fall Injuries and Related Factors of Elderly Patients at a Medical Center in Taiwan. International Journal of Gerontology. 2014;8(4):203-8.

8. Johansson J, Nordstrom A, Nordstrom P. Greater Fall Risk in Elderly Women Than in Men Is Associated With Increased Gait Variability During Multitasking. J Am Med Dir Assoc. 2016;17(6):535-40.

9. Fuller GF. Falls in the Elderly. Am Fam Physician. 2000;61(7):2159-68.

10. Schwendimann R, Buhler H, De Geest S, Milisen K. Characteristics of hospital inpatient falls across clinical departments. Gerontology. 2008;54(6):342-8.

11. Abreu C MA, Monteiro J, Santos FR. Falls in hospital settings: a longitudinal study. Rev Lat AM Enfermagem 2012;20(3):597-603.

12. Schwendimann R, Bühler H, De Geest S, Milisen K. Falls and consequent injuries in hospitalized patients: effects of an interdisciplinary falls prevention program. BMC Health Serv Res. 2006;6:69.

13. Muir SW, Gopaul K, Montero Odasso MM. The role of cognitive impairment in fall risk among older adults: a systematic review and meta-analysis. Age and Ageing. 2012;41(3):299-308

14. Segev-Jacubovski O, Herman T, Yogev-Seligmann G, Mirelman A, Giladi N, Hausdorff JM. The interplay between gait, falls and cognition: can cognitive therapy reduce fall risk? Expert review of neurotherapeutics. 2011;11(7):1057-75.

15. Bridenbaugh SA, Kressig RW. Motor cognitive dual tasking: early detection of gait impairment, fall risk and cognitive decline. Z Gerontol Geriatr. 2015;48(1):15-21.

16. Vance E, Delbaere K, Sturnieks D, Haveland S, Lord S. Nutritional status and falls: a mini review. NSW Falls Prevention Network. 2016:3:1-7. 